\title{
Seasonal Variation in Flocculation Potential of River Water: Roles of the Organic Matter Pool
}

\author{
Byung Joon Lee ${ }^{1, *}$, Jin Hur ${ }^{2}$ and Erik A. Toorman ${ }^{3}$ \\ 1 Department of Construction and Environmental Engineering, Kyungpook National University, \\ 2559 Gyeongsang-daero, Sangju, Gyeongbuk 742-711, Korea \\ 2 Department of Environment \& Energy, Sejong University, Seoul 143-747, Korea; jinhur@sejong.edu \\ 3 Hydraulics Laboratory, Department of Civil Engineering, KU Leuven, Kasteelpark Arenberg 40, \\ Heverlee B-3001, Belgium; erik.toorman@kuleuven.be \\ * Correspondence: bjlee@knu.ac.kr; Tel.: +82-54-530-1444
}

Academic Editor: Thilo Hofmann

Received: 7 February 2017; Accepted: 5 May 2017; Published: 8 May 2017

\begin{abstract}
Organic matter in the water environment can enhance either flocculation or stabilization and, thus, controls the fate and transportation of cohesive sediments and causes seasonal variation in the turbidity of river water, determining floc morphology and settling velocity. The aim of this study was to elucidate the way that biological factors change the organic matter composition and enhances either flocculation or stabilization in different seasons. Jar test experiments were performed using a mixture of standard kaolinite and the filtered river water samples collected (bi-)weekly or monthly from April to December 2015 upstream a constructed weir in Nakdong River, to estimate the flocculation potential of the seasonal river water samples. Chlorophyll-a concentration, algae number concentration, and the fluorescence characteristics of organic matter were used to represent the biological factors. Our results revealed that flocculation potential depended not only on the algal population dynamics, but also the origins (or chemical composition) of organic matter in the river water. Extracellular polymeric substances (EPS), as algal organic matter, enhanced flocculation, while humic substances (HS), as terrestrial organic matter, enhanced stabilization, rather than flocculation. Since flocculation potential reached its maximum around the peaks of algal population, algae-produced EPS likely enhanced flocculation by binding sediment particles in the flocs. This observation supports previous findings of seasonal variation in EPS production and EPS-mediated flocculation. However, when HS was transported from the surrounding basin by a heavy rainfall event, cohesive sediments tended to be rather stabilized. Supplementary flocculation potential tests, which were performed with artificial water containing refined EPS and HS, also showed the opposing effects of EPS and HS.
\end{abstract}

Keywords: cohesive sediment; flocculation; algae; extracellular polymeric substances; humic substances

\section{Introduction}

Micrometer-sized cohesive sediments are usually present in suspended forms in rivers, which make the river water turbid. The turbidity of river water may vary seasonally and spatially. For example, a heavy storm can result in more turbid river water due to the production of cohesive sediments from land disturbance and soil runoff $[1,2]$. In contrast, biota-rich rivers tend to be less turbid because biota have the ability to trap cohesive sediments through flocculation, sedimentation, and filtration [3-5]. Although the seasonality of river turbidity is obvious, the associated processes and mechanisms behind this phenomenon remain poorly understood.

Flocculation is one of the most important processes for controlling the turbidity of river water [6]. It controls the floc size and settling velocity of cohesive sediments. The flocculation potential of river 
water is affected by various physical, chemical, and biological factors. For example, flow velocity and turbulence (depending on its intensity) promote aggregation of cohesive sediments or disaggregation (i.e., breakage) of large flocs [6-8]. Water chemistry parameters, such as $\mathrm{pH}$, salinity, and multivalent cations, may change the attractive and repulsive forces of cohesive sediments [9,10]. Extracellular polymeric substances (EPS) can enhance flocculation as a polymeric flocculation agent $[11,12]$. Such biological factors are considered the main drivers of seasonality of turbidity.

Biologically-mediated flocculation, in which EPS plays a key role [12,13], has been highlighted in recent years [14-16]. Aquatic microorganisms produce EPS to allow aggregation of individual cells, forming a bigger microbial community. Otherwise, they would be easily isolated from their habitat. Similarly, EPS, due to its sticky nature, binds cohesive sediments to large flocs, affecting the fate and transportation of the sediments. Large flocs of cohesive sediments, once combined with EPS, are finally subject to sedimentation and deposition on the riverbed. EPS also combines biomass, such as microorganisms and cell debris, with sediments and forms bio-mineral flocs. The mineral and biological contents of such bio-mineral flocs determine floc size, morphology, and density, and control the overall SPM dynamics $[17,18]$. Both EPS production and EPS-mediated flocculation depend on biological activity, which varies seasonally $[11,19,20]$.

Recently, many weirs have been constructed and have begun operation in the major rivers of Korea. This weir construction has resulted in increased water depths and storage, but decreased the flow velocity of the rivers [21]. The rivers started showing lacustrine characteristics, which also changed the fate and transportation of cohesive sediments [22,23]. Such rivers cannot maintain flow-driven energy high enough to suspend cohesive sediments, resulting in increased flocculation, sedimentation, and deposition of cohesive sediments. Furthermore, a longer hydraulic retention time of weir-constructed rivers may stimulate biological growth and EPS production, accelerating the flocculation phenomenon.

For efficient management of cohesive sediments in such low-flow rivers, the formation of cohesive sediments and the underlying mechanisms need to be understood better. In this study, we hypothesized that the organic matter composition of river water affects flocculation potential, and hence, we focused on elucidating how biological domains change the organic matter composition and enhance either flocculation or stabilization of cohesive sediments via one year of monitoring data of low-flow rivers. Chlorophyll-a, algae number concentration and the fluorescence characteristics of organic matter have been looked at in the hope that the relationships between these biological factors and flocculation potential could be revealed.

\section{Materials and Methods}

\subsection{Study Site and Sampling}

The study site and sampling points are located in Nakdong River, a major river in Korea. The river is located in Southeastern Korea and has a drainage area of $23,384 \mathrm{~km}^{2}$ (Figure 1). The river and river basin undergo seasonal changes in climate, fauna and flora. The water temperature of the river varies from $5{ }^{\circ} \mathrm{C}$ to $30^{\circ} \mathrm{C}$ throughout the year. The rainfall in the river basin also varies seasonally, including monsoons during the summer season. It is important to note that Nakdong River now has movable weirs, which were constructed in 2011. The weirs have caused significant changes to the river environment. In this study, a river section between the two weirs in Nakdong River was selected as the study site (Figure 1). Since this river section has a large contribution of organics and nutrients from a tributary (Geumho River) that passes through a large city (Daegu Metropolitan City), it is subjected to high nutrient enrichment and algal blooms.

From April to December 2015, river water samples were taken at different intervals, depending on the algal population. The water samples were collected weekly, when the algal population was high (i.e., during an algal bloom period), and monthly, when the algal population was low. The river water samples were taken immediately upstream of the Dalsung weir (W2 in Figure 1) with a deep-water sampler (Changshin Science, Seoul, Korea) at $1 \mathrm{~m}$ below the surface to avoid floating matter from the 
surface. The collected water samples underwent water quality measurements $(\mathrm{pH}$, temperature, and dissolved oxygen) immediately. Subsequently, the samples were filtered through $1.2 \mu \mathrm{m}$ pore-size GF-C filter paper (Hyundai Micro, Seoul, Korea) to remove several micrometer-sized algal microorganisms, but retain submicron-sized organic matter in the river water samples. Organic matter contains humic substances and other biopolymers (e.g., polysaccarides and proteins), of which molecular weights are up to several thousands and millions $\mathrm{g} / \mathrm{mol}$, respectively $[17,18]$. Regarding the size (i.e., molecular weight) of organic matter, some biopolymers with extremely high molecular weights might be filtered out by the $1.2 \mu \mathrm{m}$ pore size filter paper. To elucidate the role of organic matter in flocculation, we made the experimental system simple, excluding algal microorganisms from the system. The filtrates, with only organic matter, were used for the flocculation potential tests, to measure/quantify the flocculation potential of the river water samples.

In addition, water quantity (e.g., water depth and flow rate) and quality data (e.g., chlorophyll-a and blue-green algae number concentration) were obtained from two national monitoring stations in the studied river section (M1 and M2 in Figure 1). Water depth was monitored at the M1 station, and flow rate was then estimated based on a rating curve. Chlorophyll-a concentration was measured with acetone extraction followed by absorbance spectroscopy, and blue-green algae number concentration was measured with the most probable number (MPN) method [24-26]. Blue-green algae number concentration was monitored as a specific measure of the harmful algal bloom (HAB) population that produces the toxin microcystin, whereas chlorophyll-a concentration is an indicator of the entire algal population. Annual rainfall intensity data were collected from the M1 monitoring station. The water quantity and quality data are available on the publicly accessible websites $[27,28]$.

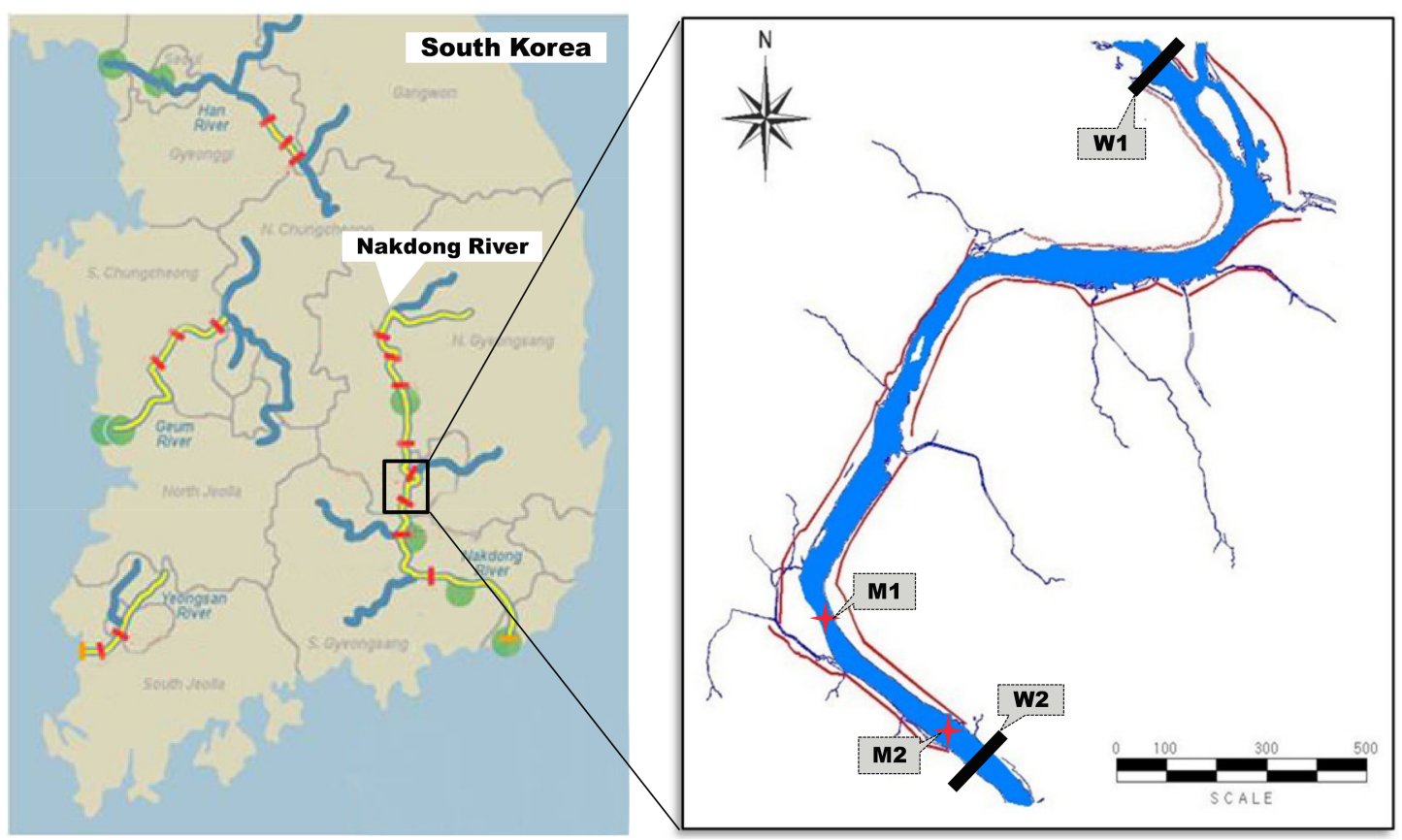

Figure 1. Map of the study site, including a section of the Nakdong River from the Goryeong weir to the Dalsung weir. The points on the map represent the weirs, the water quantity and quality monitoring stations, and the sampling sites.

\subsection{Flocculation Test}

A flocculation potential test was performed using a standard jar tester (MS-SF6, Misung, Yangju, Korea), to estimate the flocculation potential of a collected and filtered river water sample, adopting the experimental method proposed by Lee and coworkers [29]. Before the flocculation potential test, a kaolinite (Sigma-Aldrich, St. Louis, MO, USA) stock suspension was prepared at $20 \mathrm{~g} / \mathrm{L}$ with 
$0.001 \mathrm{M} \mathrm{NaCl}$ as the background salt concentration and adjusted to a $\mathrm{pH}$ of 7. Kaolinite was used as the model clay particle because it is one of the most abundant clay species in the study site and has been widely used in earlier studies. The size range of kaolnite was reported as $0.1-4 \mu \mathrm{m}$ by the manufacturer. The kaolinite suspension was stirred for a day to achieve full saturation with water. Then, the six jars of the jar tester were filled with up to $2 \mathrm{~L}$ with six different volumes of the kaolinite stock solution and the filtrate of the river water sample. The kaolinite concentrations of the six jars were set at $0.1,0.2,0.5$, $1.0,1.5$, and $2.0 \mathrm{~g} / \mathrm{L}$. Afterward, the mixtures of the kaolinite suspension and the filtrate were mixed rapidly at $200 \mathrm{rpm}(\mathrm{G} \approx 250 / \mathrm{s})$ for $2 \mathrm{~min}$ to homogenize the mixture and mixed slowly at $50 \mathrm{rpm}$ $(G \approx 45 / \mathrm{s})$ for $6 \mathrm{~h}$ to promote flocculation. The shear rate $(G)$ was rather fixed for simplicity, although the shear rate varies widely from a few to hundreds in the water environment. The flocculation potential test was also applied for the artificial water samples containing the commercially refined EPS (xanthan gum, Sigma-Aldrich, St. Louis, MO, USA) and the humic substances (HS) (humic acid sodium salt, Sigma-Aldrich, St. Louis, MO, USA), to investigate the effect of the organic matter pool on flocculation under controlled experimental conditions. The three artificial water samples were prepared at $\mathrm{pH} 7$ and $0.001 \mathrm{M}$ of ionic strength, containing different amounts of xanthan gum and HS. A fixed amount of xanthan gum was dosed to the artificial water samples at $10 \mathrm{mg} / \mathrm{L}$, equivalent to $2.34 \mathrm{mgTOC} / \mathrm{L}$. However, different amounts of HS were dosed at $0,0.5$, and $2 \mathrm{mg} / \mathrm{L}$, to investigate EPS-mediated flocculation and HS-mediated stabilization. After $6 \mathrm{~h}$ of stirring, enough for flocculation to reach a steady state, suspended flocs were taken carefully with a spatula from each jar for floc size measurement. After an additional $1 \mathrm{~h}$ of settling without mixing, a supernatant aliquot was taken from each jar to determine the residual suspended solids concentration in the water column above the mud deposit.

\subsection{Measurement of Flocculation Potential Indices}

The floc fixation method utilized agar plates to prevent floc movement and growth in measurement and photographic image processing to measure the size and morphology of flocs $[29,30]$. After $6 \mathrm{~h}$ of stirring, suspended flocs were removed from the jar tester and immediately fixed on a liquefied agar plate. Then, the plate was cooled to room temperature $\left(25^{\circ} \mathrm{C}\right)$ to solidify the gel and prevent further changes to the floc structure. Microscopic images of the fixed flocs were recorded with a Sony Alpha 6000 camera, equipped with a Sony $30 \mathrm{~mm}$ f3.5 macro lens (Sony, Tokyo, Japan). The microscopic images has the resolution at $3.9 \mu \mathrm{m} /$ pixel. The raw images with $6000 \times 4000$ pixels were processed with public domain image processing software (Image J, National Institutes of Health, MD, USA). Volume-averaged floc diameters were calculated with a built-in function in the software after performing some image processing (e.g., adjusting image contrast or brightness and deleting unclear floc images) (Figure 2). The steps of sampling, fixing, and imaging flocs were replicated three times for each jar test. Usually, each photographic image of a collected sample contained tens to hundreds of flocs, which were then used to calculate the volume-averaged diameter of the sample. Due to the resolution limit of the camera, the minimum measurable floc size was set at $20 \mu \mathrm{m}$. In other words, flocs smaller than $20 \mu \mathrm{m}$ were deleted prior to calculating the volume-averaged floc diameter. Consequently, the volume-averaged floc diameters that we report in this paper do not fully reflect the range of particle sizes that were present but instead are somewhat higher than the "true" volume-averaged diameters would have been. In this paper, we use the volume-averaged floc diameters primarily as a relative indicator of the flocculation potential for each test condition. In addition, as a flocculation potential index, residual suspended solids concentrations were determined following Standard Methods 2540D, Total Suspended Solids (APHA, 1998). Each sample aliquot taken after an hour of settling was filtered through a pre-weighed $0.2 \mu \mathrm{m}$ membrane filter (Hyundai Micro, Seoul, Korea). Then, the filter with its collected solids was dried at $105{ }^{\circ} \mathrm{C}$, reweighed, and the mass of collected solids determined as the difference in weight. 


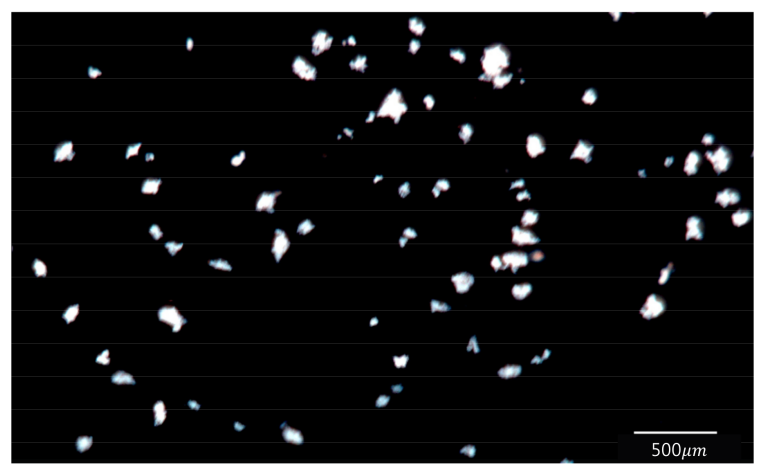

(a)

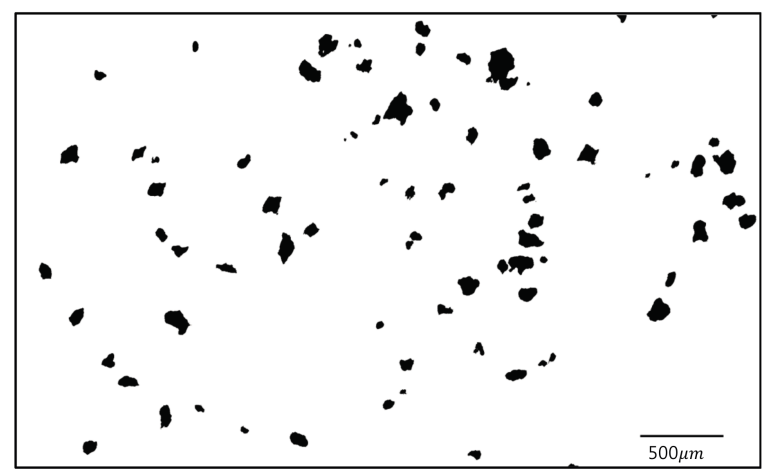

(b)

Figure 2. (a) A raw image; and (b) a processed image of a fixed floc sample on an agar plate.

\subsection{Measurement of Organic Matter Characteristics}

To investigate the characteristics of the organic matter in the river water samples, we adopted several analytical tools, including dissolved organic carbon (DOC), specific UV absorbance (SUVA), and fluorescence excitation-emission matrices and parallel factor (FEEM-PARAFAC) analyses [31]. The river water samples, filtered through $1.2 \mu \mathrm{m}$ GF-C filter paper (Hyundai Micro, Seoul, Korea), were kept in a freezer prior to the chemical analyses. First, the DOC concentration was determined using a Shimadzu TOC-L analyzer (Shimadzu, Kyoto, Japan). For the SUVA and FEEM-PARAFAC analyses, the samples were adjusted to $\mathrm{pH} 3$ by adding $1 \mathrm{M} \mathrm{HCl}$ prior to the absorbance and fluorescence measurements to minimize the potential interference of $\mathrm{pH}$ variability and metal bindings. $\mathrm{UV}$ absorbance at $254 \mathrm{~nm}$ was measured with a Hach DR5000 UV-visible spectrophotometer (Hach, Loveland, CO, USA), with Milli-Q water as the blank. SUVA was calculated by dividing 100-fold UV absorbance at $254 \mathrm{~nm}$ with DOC, which has been shown to correlate positively with the aromaticity of dissolved organic matter (DOM) [32]. The FEEMs of the samples, diluted until UV254 $<0.05 \mathrm{~cm}^{-1}$, were scanned using a Perkin-Elmer LS-55 luminescence spectrometer over excitation/emission wavelengths of 250-500 nm and $280-550 \mathrm{~nm}$ at increments of $5 \mathrm{~nm}$ and $0.5 \mathrm{~nm}$, respectively. The FEEM of each sample was subjected to blank subtraction and normalized by the Raman peak of Milli-Q water excited at $350 \mathrm{~nm}$. The detailed procedures of fluorescence EEMs are found elsewhere [33,34]. The FEEM results of the twenty collected samples were statistically analyzed via PARAFAC modeling, using MATLAB software with the DOMFluor toolbox [35]. The number of components was determined based on split-half analysis. We also estimated the humification index (HIX), denoted as the ratio of the areas in the upper $(435-380 \mathrm{~nm})$ to the lower $(300-445 \mathrm{~nm})$ quarters of the emission wavelength range [36,37].

\section{Results and Discussion}

\subsection{Seasonal Variation in Algal Population and Organic Matter}

The chlorophyll-a and blue-green algae number concentration data indicated that the algal population peaks were triggered by rising water temperature in the river (Figure 3). When water temperature was over $25{ }^{\circ} \mathrm{C}$ during the summer season (June to September), chlorophyll-a and blue-green algae number concentrations reached several peaks, indicating algal blooms. In the summer season, the dominant algal species was found to be Microcystis, a genus of blue-green algae (i.e., Cyanobacteria). However, in the remaining seasons, the dominant algal species was mostly Aphanizomenon.

The chlorophyll-a and blue-green algae number concentrations were not constantly high during the summer season. The algal population peaks were followed by sudden decreases, which were probably caused by nutrient depletion, light attenuation and/or algae washout [38]. Considering high precipitation is concentrated during the summer season in Korea, the sudden drops in algal 
population probably resulted from heavy rainfalls during large storms. For example, after a series of heavy rainfalls and high flow rates from 25 June to 9 July 2015, chlorophyll-a and blue-green algae number concentrations dropped to background levels. A similar phenomenon took place after the precipitation from 20 to 25 August 2015.

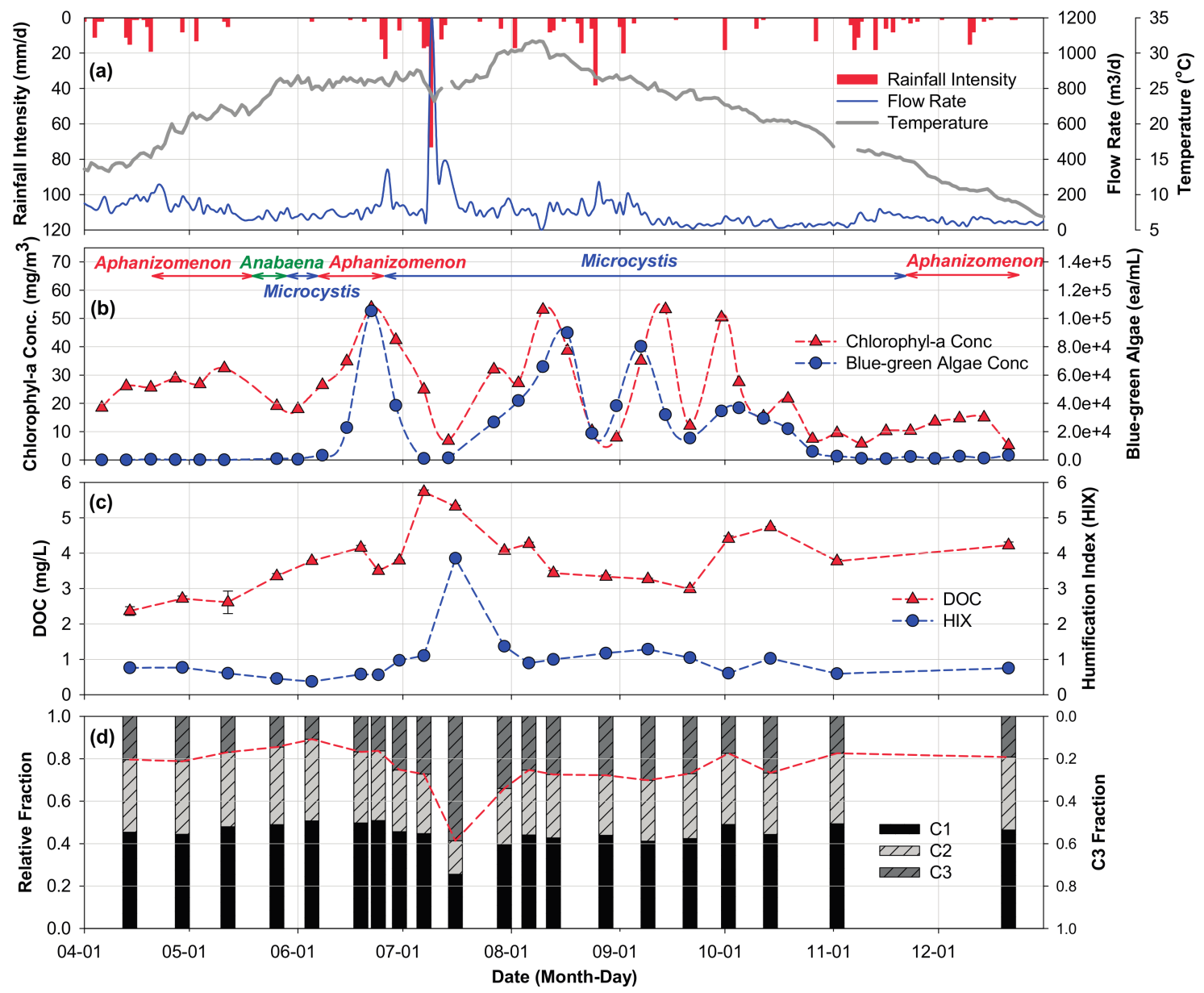

Figure 3. Seasonal variation in the physical and biogeochemical indicators of (a) rainfall intensity, flow rate, and temperature; (b) chlorophyll-a concentration and blue-green algae concentration; (c) dissolved organic carbon (DOC); and (d) relative fractions of the organic matter components.

FEEM-PARAFAC analysis revealed that a three-component model could represent the variations in fluorescent DOM in all the collected river water samples. As shown in Figure 4, the three-component model consists of components C1, C2, and C3, which have excitation/emission maxima (i.e., peaks) at $\leq 225 / 345 \mathrm{~nm}, \leq 225(275) / 320 \mathrm{~nm}$, and 230/430 nm, respectively. Based on a comparison with previous FEEM-PARAFAC studies [39-43], the three components, C1, C2, and C3, could be assigned to protein-like, tryptophan-like, and humic-like fluorescent DOM, respectively (Table 1). DOM in rivers and lakes is characterized by a heterogeneous mixture of algal (autochthonous) and terrestrial (allochthonous) organic matter [44,45]. The protein-like C1 and tryptophan-like C2 could originate from algal organic matter. EPS, considered a natural flocculation agent, form a specific group of algal organic matter. In contrast, the humic-like C3 is likely to be associated with terrestrial organic matter exported from surrounding catchments [39,40,43].

The algal (C1 and C2) and the terrestrial (C3) organic matter exhibited dynamic changes in their relative proportions depending on seasons and rain events. The heavy rainfall events during the summer rainy season led to drastic changes in fluorescent organic matter composition. The heaviest rainfall on 8 July 2015 increased the relative abundance of the humic-like C3 component from 27\% to 
$59 \%$. The humification index (HIX) also increased from 1.10 to 3.85 after the rain event (Figure 3). This observation suggests that a large amount of HS, i.e., terrestrial organic matter, was transported from the surrounding basins to the river.
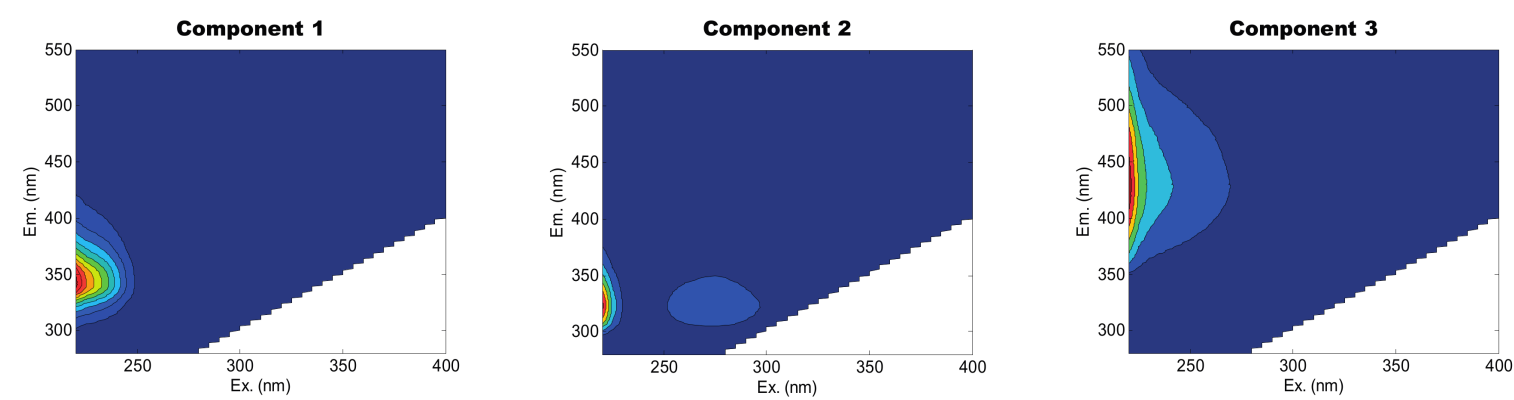

Figure 4. Typical excitation-emission matrices for the river water samples. The respective abbreviations of Em and Ex represent the excitation and emission wavelengths of the FEEM-PARAFAC analysis.

Table 1. Characteristics of the fluorescence excitation-emission matrices (FEEM) peaks in this study and commonly-observed FEEM peaks from previous studies. Values in brackets represent secondary peaks.

\begin{tabular}{|c|c|c|c|c|}
\hline \multicolumn{2}{|c|}{ This Study } & \multicolumn{3}{|c|}{ Previous Study } \\
\hline $\mathrm{C}$ & $\lambda_{\mathrm{ex}} / \lambda_{\mathrm{em}}$ & $\lambda_{\mathrm{ex}} / \lambda_{\mathrm{em}}$ & Ref. & Description \\
\hline $\mathrm{C} 1$ & $\leq 225 / 345$ & $\begin{array}{c}\leq 225(285) / 344 \\
225-230(275) / 340-350 \\
225(280-285) / 340-350\end{array}$ & $\begin{array}{l}\text { Zhang et al. [43] } \\
\text { Coble [39,40] } \\
\text { Sheng and Yu [42] }\end{array}$ & $\begin{array}{l}\text { Autochthonous } \\
\text { tryptophan-like fluorescence, } \\
\text { including EPS }\end{array}$ \\
\hline $\mathrm{C} 2$ & $<225(275) / 320$ & $\begin{array}{c}\leq 225(275) / 322 \\
225-230(275) / 305-310 \\
\end{array}$ & $\begin{array}{c}\text { Zhang et al. [43] } \\
\text { Coble }[39,40]\end{array}$ & $\begin{array}{l}\text { Autochthonous tyrosine-like } \\
\text { fluoresence }\end{array}$ \\
\hline $\mathrm{C} 3$ & $230 / 430$ & $\begin{array}{c}255(350) / 471 \\
230-260 / 380-460 \\
\leq 250 / 400-460\end{array}$ & $\begin{array}{c}\text { Zhang et al. [43] } \\
\text { Coble [39,40] } \\
\text { Osburn et al. [41] }\end{array}$ & $\begin{array}{l}\text { Terrestrial humic-like } \\
\text { substances }\end{array}$ \\
\hline
\end{tabular}

\subsection{Seasonal Variation in Flocculation Potential}

The seasonality of the algal population and the organic matter composition was illustrated in Figure 3. It was initially hypothesized that EPS production from algae could enhance the flocculation potential of the river water based on previous studies that reported high linkage between algal population dynamics (or EPS production) and flocculation potential [11,14,46]. The peak concentration of chlorophyll-a (i.e., phytoplankton) was followed by the maxima of EPS production and flocculation potential $[19,47,48]$. However, it should be noted that the influence of DOM composition on flocculation might be more complicated because HS can also influence the flocculation potential. For example, it was previously reported that negatively-charged HS with relatively small molecular weight (500-200,000 Da) reduced flocculation and enhanced the stabilization of cohesive sediments [49-51].

Figure $5 \mathrm{a}, \mathrm{b}$ show the representative results of the flocculation potential tests based on river waters with low and high flocculation capabilities, respectively. In general, as the kaolinite concentrations (x-axis in Figure 5) increased from $0.1 \mathrm{~g} / \mathrm{L}$ to $2.0 \mathrm{~g} / \mathrm{L}$, the floc diameters $\left(\mathrm{D}_{\text {Floc }}\right.$ ) and the normalized ratios of the suspended residual solid concentration against the total concentration in the water column (i.e., C/Co) decreased, approaching their lowest values. The low flocculation potential test (Figure 5a) indicated that $\mathrm{D}_{\text {Floc }}$ was consistently small, close to the measurement threshold (i.e., $20 \mu \mathrm{m}$ ), and C/Co was relatively high, ranging from $20 \%$ to $80 \%$ with varying kaolinite concentration. However, in the high flocculation potential test (Figure $5 \mathrm{~b}$ ), $\mathrm{D}_{\text {Floc }}$ was larger, with $90 \mu \mathrm{m}$ at $0.1 \mathrm{~g}$ kaolinite/L and the $\mathrm{C} / \mathrm{Co}$ ratios were lower, ranging from $10 \%$ to $35 \%$. Large $\mathrm{D}_{\mathrm{Floc}}$, in the high flocculation potential test, was necessarily followed by a decrease in C/Co because large flocs settle quickly to the bottom, subsequently reducing the residual solids in the water. It is also important to note that a lower kaolinite dose concentration (e.g., 0.1 or $0.2 \mathrm{~g} / \mathrm{L}$ ) resulted in large organic matter-dominant flocs, but a higher kaolinite dose concentration (e.g., 1.5 or $2.0 \mathrm{~g} / \mathrm{L}$ ) resulted in relatively small mineral-dominant flocs. 
A sediment-rich water usually results in small and dense flocs, whereas an organic matter-rich water produces large and fluffy flocs. For example, small mineral-dominant flocs were often observed in a turbid water with much sediments, whereas large organic matter-dominant flocs were found in a water containing much organic matter and a little sediment $[52,53]$.
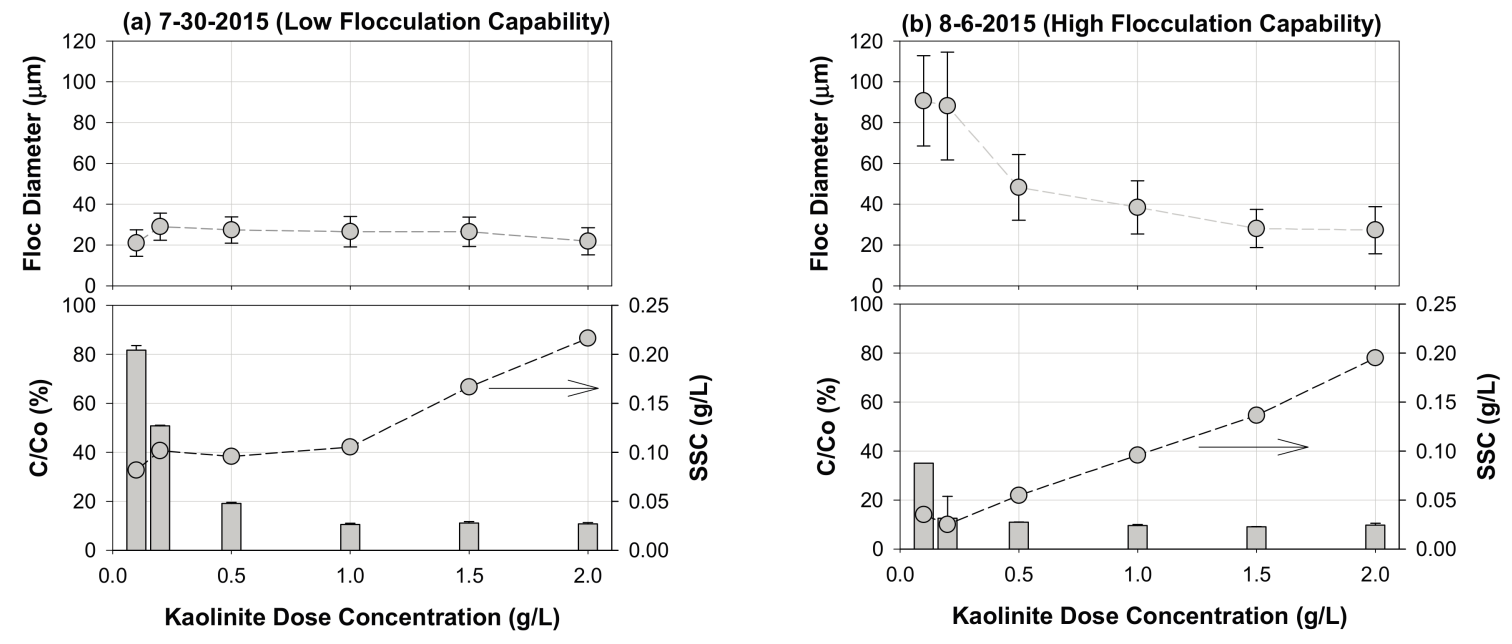

Figure 5. Typical results from the flocculation potential tests with (a) a low flocculation potential (measured on 30 July 2015); and (b) a high flocculation potential (on 6 August 2015). The top panel of each figure shows the floc diameters $\left(\mathrm{D}_{\mathrm{Floc}}\right)$, and the bottom panel shows the normalized ratios of the residual solid concentration $(\mathrm{C} / \mathrm{Co})$ and the suspended solid concentration (SSC).

The results of all the flocculation potential tests for the studied year are summarized in Figure 6, which clarify how the algal population and DOM characteristics affected the flocculation potential of the river water. Around the first peak of chlorophyll-a concentration, corresponding to the period from 15 June to 15 July 2015, $D_{\text {Floc }}$ increased to approximately $60 \mu \mathrm{m}$. Algal blooms, indicated by a peak in chlorophyll-a concentration, might increase EPS production and EPS-mediated flocculation, as reported previously [11,12]. However, when the rainy season started on 25 June 2015, C/Co started increasing. After a heavy rainfall event on 8 July 2015, C/Co further increased, up to $80 \%$, and $D_{\text {Floc }}$ drastically decreased to the measurement threshold $(20 \mu \mathrm{m})$. As described in Section 3.1, HS as a dispersant, transported from the river basins to the river, might reduce the flocculation potential of the river water. Once the river water was disturbed by the heavy rainfalls and the influx of $\mathrm{HS}$, the flocculation potential of the river water remained low, with small $\mathrm{D}_{\text {Floc }}$ and high $\mathrm{C} / \mathrm{Co}$, except for a couple of sudden rises of $\mathrm{D}_{\text {Floc }}$ and sinks of $\mathrm{C} / \mathrm{Co}$. After the disturbance by the heavy rainfall, it was hard to identify a correlation between the biological factors and the flocculation potential. The incoming HS likely hindered flocculation, stabilizing sediments and, hence, concealed the bio-floc correlation.

Figure 7 shows the separate experimental results from the individual flocculation potential tests on the samples before and at the first peak of the flocculation potential. When the algal population (i.e., chlorophyll-a and blue-green algae number concentrations) was low, around the background level, on 5 June 2015, D Floc was small, at under $30 \mu \mathrm{m}$, and C/Co was $35 \%$, at most, at $0.1 \mathrm{~g}$ kaolinite/L, indicating a relatively low flocculation potential (Figure 7a). As the algal population increased, on 24 June 2015, $\mathrm{D}_{\text {Floc }}$ increased to $60 \mu \mathrm{m}$ and C/Co decreased to $12 \%$ at $0.1 \mathrm{~g}$ kaolinite/L, indicating an increase of the flocculation potential (Figure $7 \mathrm{~b}$ ). Just after the peak of the algal population, on 7 July 2015, $D_{\text {Floc }}$ further increased and remained high at approximately $60 \mu \mathrm{m}$ for all the kaolinite concentrations (Figure 7c). This observation supports the argument of van der Lee [19] that maximum flocculation occurred shortly after peak algal population, i.e., algal bloom $[19,20]$. However, on 7 July 2015, C/Co had an opposing tendency against $\mathrm{D}_{\text {Floc }}$. C/Co increased from $12 \%$ at $0.1 \mathrm{~g}$ kaolinite/ $\mathrm{L}$ on 24 June 2015 , to $55 \%$ on 7 July 2015 , indicating a decrease in the flocculation potential. Thus, flocculation 
and stabilization appear to occur simultaneously with an influx of $\mathrm{HS}$ because both $\mathrm{D}_{\text {Floc }}$ and C/Co increased at the same time.

After the heaviest rainfall on 8 July 2015, $\mathrm{D}_{\mathrm{Floc}}$ decreased to $20-30 \mu \mathrm{m}$ for all the kaolinite concentrations and $\mathrm{C} / \mathrm{Co}$ increased to $76 \%$ at $0.1 \mathrm{~g}$ kaolinite/ $\mathrm{L}$, indicating a significant decrease in the flocculation potential (Figure 7d). A large amount of HS, which was transported from the river basins by the heaviest rainfall, might work as a dispersant and decrease the flocculation potential of the river water. As shown in Section 3.1, the FEEM-PARAFAC analysis indicated that a significant amount of the humic-like C3 component appeared in the river after the heaviest rainfall on 8 July 2015 (Figure 3).
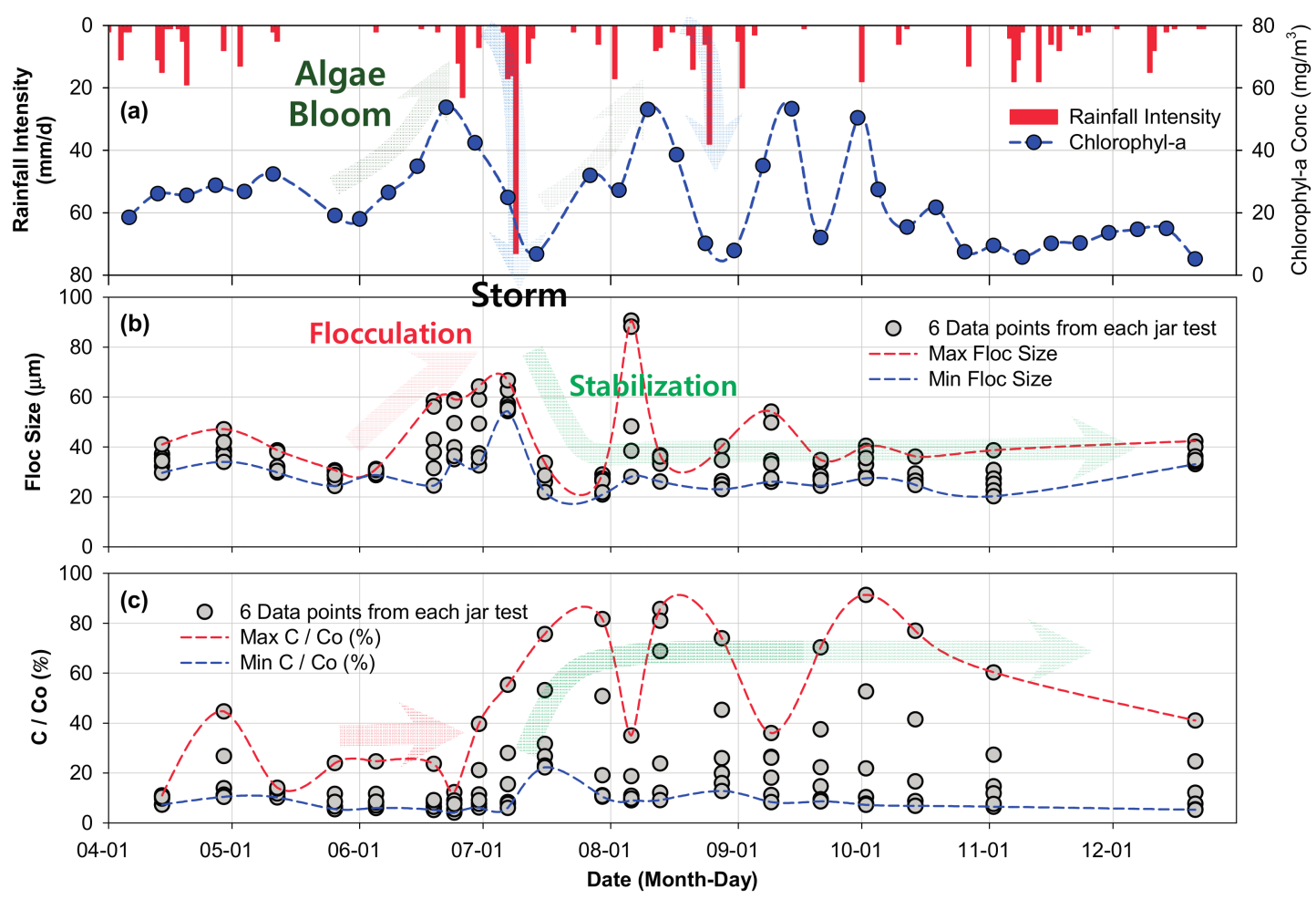

Figure 6. (a) Seasonal variation in the biochemical drivers and the flocculation potential via (b) floc diameter $\left(\mathrm{D}_{\text {Floc }}\right)$, and $(\mathbf{c})$ the normalized ratio of the residual solid concentration $(\mathrm{C} / \mathrm{Co})$.
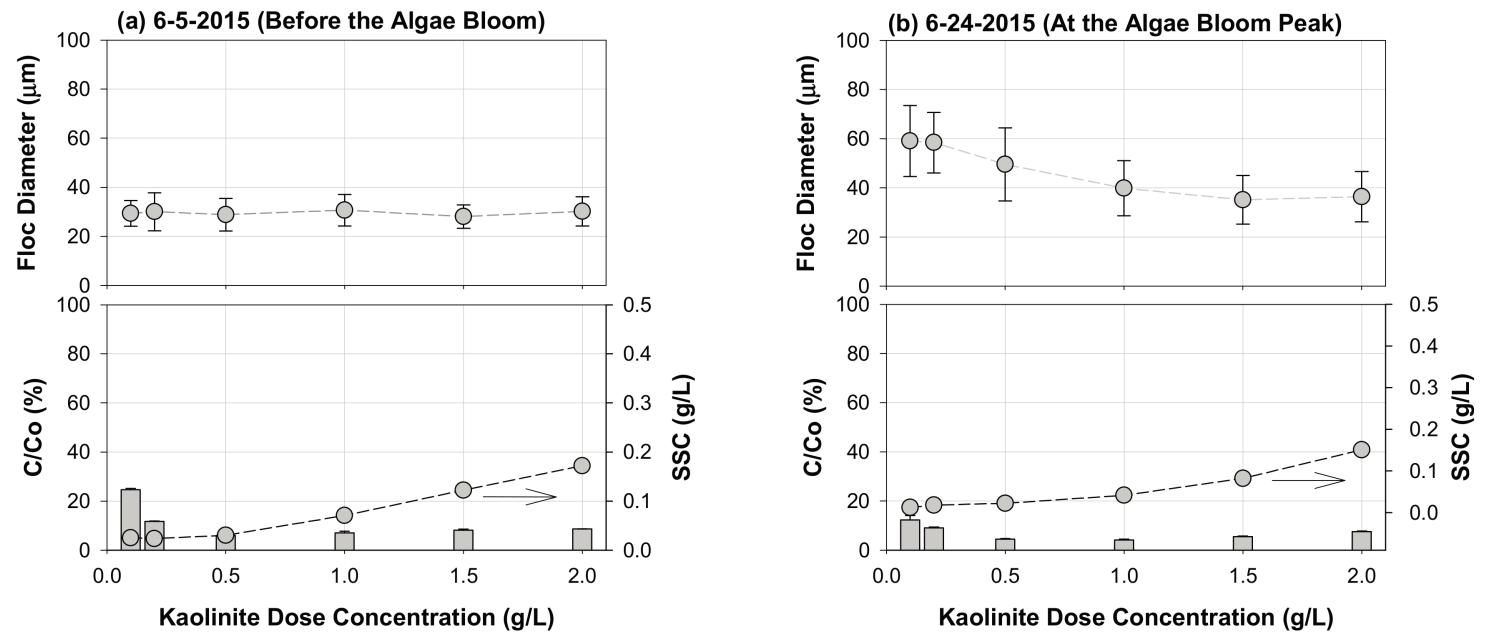

Figure 7. Cont. 

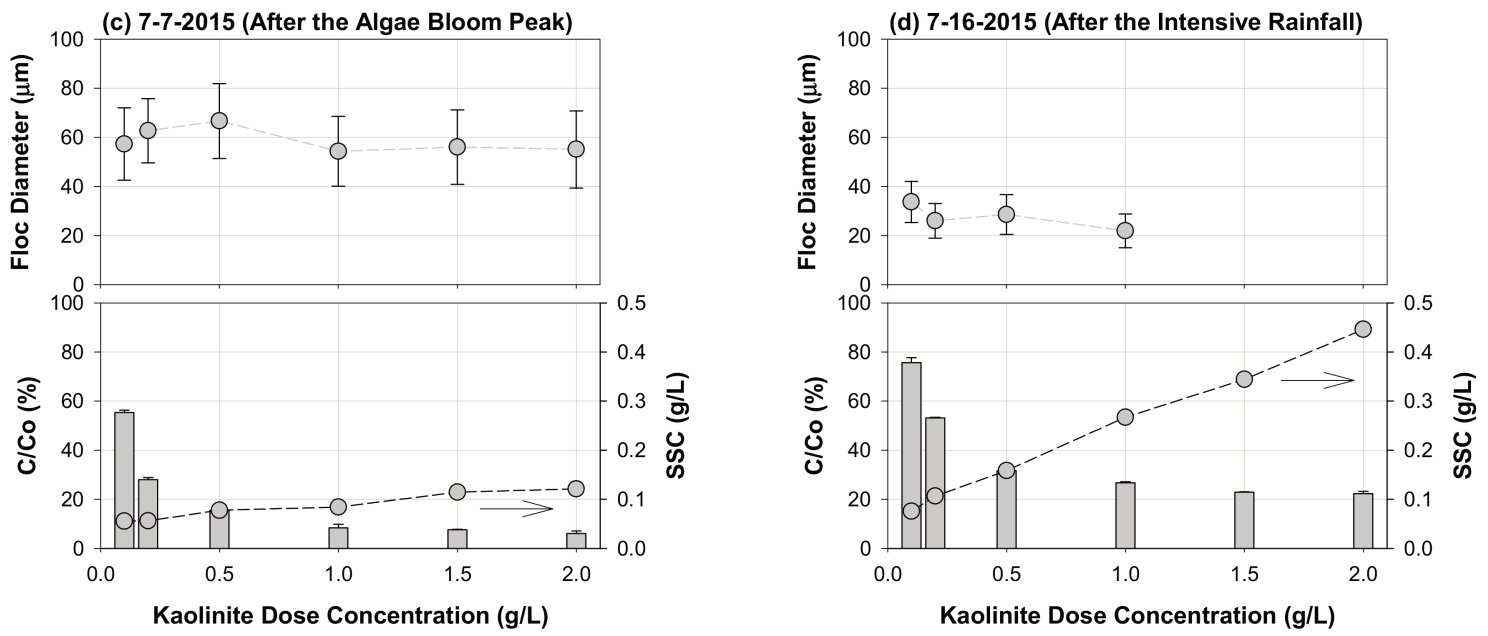

Figure 7. Typical results from the flocculation potential tests, measured (a) before the algal bloom on 5 June 2015; (b) at the peak of algal bloom on 24 June 2015; (c) after the peak of algal bloom on 7 July 2015; and (d) after the heavy rainfall on 16 July 2015.

\subsection{Flocculation in a Controlled Suspension Containing EPS and HS}

To investigate the competitive roles of EPS and HS for flocculation and stabilization, additional flocculation potential tests were conducted with artificial water containing commercially-refined EPS and HS. Addition of HS to the artificial water was found to reduce the flocculation potential, decreasing $\mathrm{D}_{\mathrm{Floc}}$ and increasing C/Co. As shown in Figure 8, as the HS concentration increased from $0 \mathrm{mg} / \mathrm{L}$ to $2 \mathrm{mg} / \mathrm{L}, \mathrm{D}_{\text {Floc }}$ generally decreased, and C/Co increased, indicating a decrease in the flocculation potential. This observation indicated that HS stabilized sediment particles as dispersants. HS have been reported to stabilize sediment particles and, hence, reduce the flocculation potential, when they are adsorbed on sediment particles [49,50].

\section{(a) Floc Diameter}

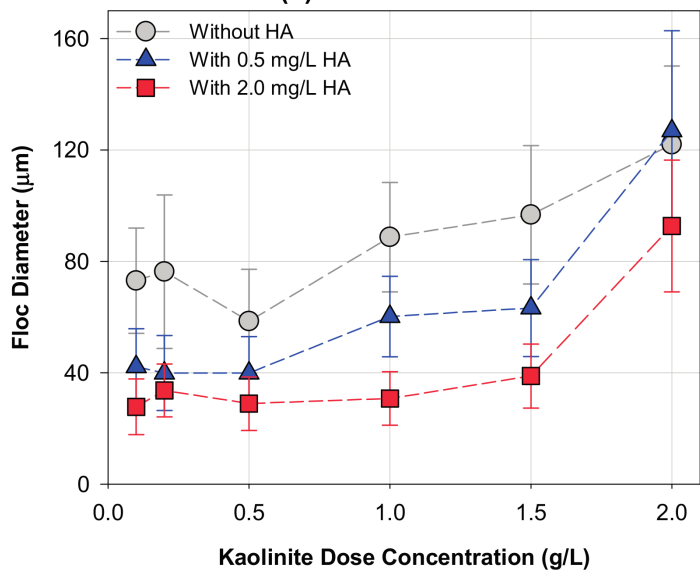

(b) Residual Solid Concentration

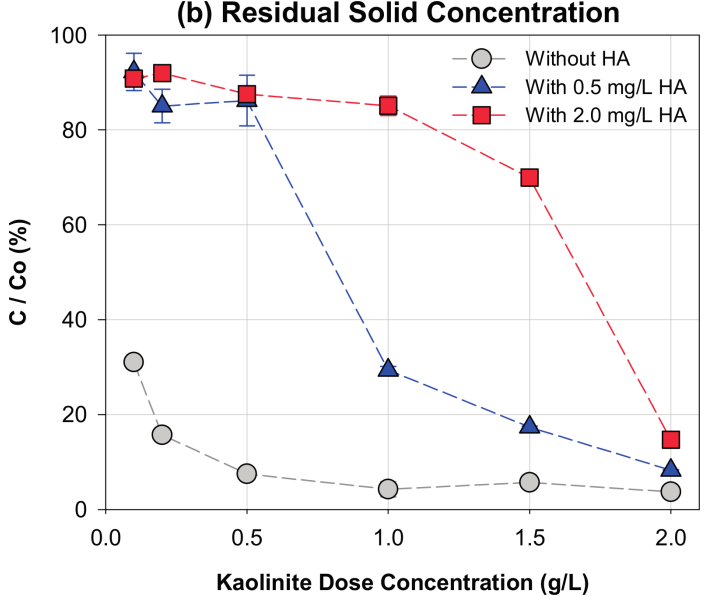

Figure 8. Results from the supplementary flocculation potential tests with artificial water containing $10 \mathrm{mg} / \mathrm{L}$ of refined extracellular polymeric substances (EPS) and 0, 0.5, and $2.0 \mathrm{mg} / \mathrm{L}$ of humic substances (HS). $(\mathbf{a}, \mathbf{b})$ show floc diameters $\left(\mathrm{D}_{\mathrm{Floc}}\right)$ and the normalized ratios of the residual solid concentration $(\mathrm{C} / \mathrm{Co})$, respectively, at increasing kaolinite concentrations.

Moreover, when both EPS and HS were present in a kaolinite suspension, HS seemed to occupy kaolinite particles and promote stabilization, dominating over EPS for the adsorption sites of kaolinite particles. As shown in Figure 8b, with the addition of $0.5 \mathrm{mg} \mathrm{HS} / \mathrm{L}, \mathrm{C} / \mathrm{Co}$ plateaued over $80 \%$ for 0.1 , 
0.2 , and $0.5 \mathrm{~g}$ kaolinite/ $\mathrm{L}$, indicating that $80 \%$ of kaolinite particles are subject to stabilization rather than flocculation. With the addition of $2.0 \mathrm{mg} \mathrm{HS} / \mathrm{L}$, the plateau of C/Co was extended further to $1.5 \mathrm{~g}$ kaolinite/L. Thus, when EPS and HS are mixed together, HS is likely to occupy kaolinite surfaces, hindering the attachment of EPS onto kaolinite particles (Figure 9). It is noteworthy that short-chain polymers, such as HS, have been reported to be more accessible to sediment particles than long-chain polymers (e.g., EPS) [54].

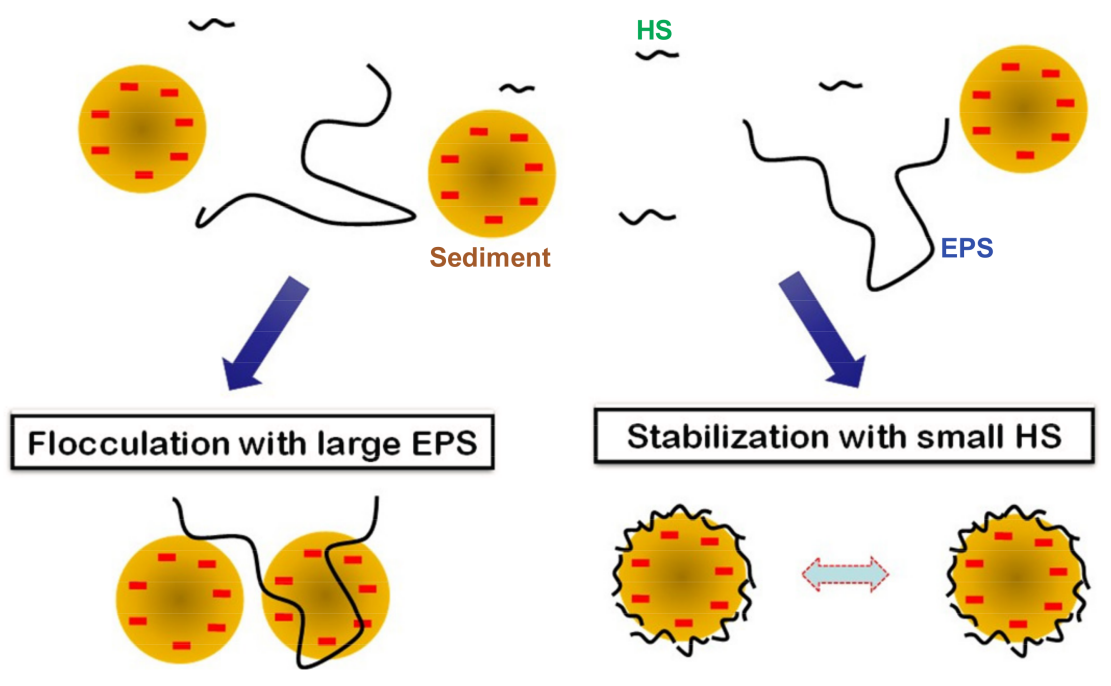

Figure 9. Schematic diagram illustrating the conceptual model of extracellular polymeric substances (EPS)-mediated flocculation and humic substance (HS)-mediated stabilization in the mixture of EPS and HS.

Kaolinite particles cannot not grow to large settleable flocs, suspending in the terrestrial water, because they are repulsive to each other with the negative surface charge at a neutral $\mathrm{pH}$ and low ionic strength of the terrestrial water environment. However, with EPS and HS, the colloidal system is subject to either flocculation (i.e., destabilization) or more stabilization [55]. Adsorbed EPS with long-chain structures builds inter-particle polymer bridges and enhances flocculation, overcoming the electrostatic repulsion of the negatively-charged particles [13,56]. However, HS, with relatively short-chain structures, are not long enough to extend out of the electrostatic repulsive layer and build polymer bridges, but rather enhances stabilization $[13,57,58]$. Anionic HS adsorption imparts more negative charge to the surface and increases the stability of kaolinite particles. In addition to the electrostatic effect, HS adsorption causes steric hindrance in that the adsorbed polymer structures on the kaolinite surfaces deter particle-particle attachment.

It is also important to note that attached microorganisms can control biologically-mediated flocculation $[16,18,53]$. Microorganisms colonize and grow on sediment particles/aggregates and build large bio-mineral flocs. Furthermore, the bio-mediated flocculation by attached microorganisms determines floc characteristics, such as size, shape, density, and settling velocity, and so on. We, thus, propose that not only organic matter (e.g., EPS and HS) but also attached microorganisms, should be investigated in an integrated way to elucidate the interactions between the mineral and the biological domains and the bio-mediated flocculation.

\section{Conclusions}

The interactions between the biotic (i.e., algae) and abiotic (i.e., cohesive sediments) domains are the main drivers causing seasonal variation in the turbidity of river water. We explored a special case of the biotic-abiotic interactions between the algal population dynamics and the flocculation of cohesive sediments in river water. A high algal population was found to increase EPS production 
and EPS-mediated flocculation of cohesive sediments in river water. This finding agrees with earlier studies reporting the seasonality of the flocculation potential [11,19]. However, this study, with the FEEM-PARAFAC analysis, further elucidated that HS (i.e., terrestrial organic matter) enhanced stabilization of cohesive sediments rather than flocculation, dominating over EPS for cohesive sediments. A heavy rainfall event during the monsoon season transported a large amount of HS from the river basins to the corresponding river, which reduced the flocculation potential of the river water. A set of controlled experiments with a mixture of refined EPS and HS validated the stabilizing role of HS by competing the attachment to sediment surfaces with EPS. In short, EPS operated as a flocculant, whereas HS functioned as a dispersant in the river water. The findings of this study point out the importance of seasonality in the biota and organic matter sources when river water turbidity and/or best water resources management are considered.

Acknowledgments: This research was supported by the Basic Science Research Program through the National Research Foundation of Korea (NRF) funded by the Ministry of Education (No. 2014R1A1A2055622).

Author Contributions: Byung Joon Lee, Jin Hur, and Erik A. Toorman conceived and designed the experiments; Byung Joon Lee and Jin Hur performed the experiments; and Byung Joon Lee, Jin Hur, and Erik A. Toorman analyzed the results and wrote the paper.

Conflicts of Interest: The authors declare no conflict of interest.

\section{References}

1. Lee, H.J.; Chun, K.W.; Shope, C.L.; Park, J.H. Multiple Time-Scale Monitoring to Address Dynamic Seasonality and Storm Pulses of Stream Water Quality in Mountainous Watersheds. Water 2015, 7, 6117-6138. [CrossRef]

2. Park, J.H.; Duan, L.; Kim, B.; Mitchell, M.J.; Shibata, H. Potential effects of climate change and variability on watershed biogeochemical processes and water quality in Northeast Asia. Environ. Int. 2010, 36, $212-225$. [CrossRef] [PubMed]

3. Craft, C.B.; Casey, W.P. Sediment and nutrient accumulation in floodplain and depressional freshwater wetlands of Gerogia, USA. Wetlans 2000, 20, 323-332. [CrossRef]

4. Johnston, C.A.; Bubenzer, G.D.; Lee, G.B.; Madison, F.W.; McHenry, J.R. Nutrient Trapping by Sediment Deposition in a Seasonally Flooded Lakeside Wetland. J. Environ. Qual. 1982, 13, 283-290. [CrossRef]

5. Ockenden, M.C.; Deasy, C.; Quinton, J.N.; Surridge, B.; Stoate, C. Keeping agricultural soil out of rivers: Evidence of sediment and nutrient accumulation within field wetlands in the UK. J. Environ. Manag. 2014, 135, 54-62. [CrossRef] [PubMed]

6. Maggi, F. Flocculation Dynamics of Cohesive Sediment. PhD Dissertation, Technische Universiteit Delft, Delft, The Netherlands, 2005.

7. Spicer, P.; Pratsinis, S. Coagulation-fragmentation: Universal steady state particle size distribution. AiChE J. 1996, 42, 1612. [CrossRef]

8. Verney, R.; Brun-Cottan, J.; Le Hir, P. Behaviour of a floc population during a tidal cycle: Laboratory experiments and numerical modelling. Cont. Shelf Res. 2011, 31, S64-S83. [CrossRef]

9. Mietta, F.; Chassagne, C.; Manning, A.J.; Winterwerp, J.C. Influence of shear rate, organic matter content, $\mathrm{pH}$ and salinity on mud flocculation. Ocean Dyn. 2009, 59, 751-763. [CrossRef]

10. Mietta, F.; Chassagne, C.; Winterwerp, J. Shear-induced flocculation of a suspension of kaolinite as function of $\mathrm{pH}$ and salt concentration. J. Colloid Interface Sci. 2009, 336, 134-141. [CrossRef] [PubMed]

11. Chen, M.S.; Wartel, S.; Temmerman, S. Seasonal variation of floc characteristics on tidal flats, the Scheldt estuary. Hydrobiologia 2005, 540, 181-195. [CrossRef]

12. Droppo, I.G. Rethinking what constitutes suspended sediment. Hydrol. Process. 2001, 15, 1551-1564. [CrossRef]

13. Furukawa, Y.; Reed, A.H.; Zhang, G. Effect of organic matter on estuarine flocculation: A laboratory study using montmorillonite, humic acid, xanthan gum, guar gum and natural estuarine flocs. Geochem. Trans. 2014, 15, 1-9. [CrossRef] [PubMed]

14. Fettweis, M.; Baeye, M. Seasonal variation in concentration, size, and settling velocity of muddy marine flocs in the benthic boundary layer. J. Geophys. Res. Oceans 2015, 120, 5648-5667. [CrossRef] 
15. Lee, B.J.; Fettweis, M.; Toorman, E.; Molz, F.J. Multimodality of a particle size distribution of cohesive suspended particulate matters in a coastal zone. J. Geophys. Res. Oceans 2012, 117, C03014. [CrossRef]

16. Maggi, F. Biological flocculation of suspended particles in nutrient-rich aqueous ecosystems. J. Hydrol. 2009, 376, 116-125. [CrossRef]

17. Maggi, F. The settling velocity of mineral, biomineral, and biological particles and aggregates in water. J. Geophys. Res. Oceans 2013, 118, 2118-2132. [CrossRef]

18. Maggi, F.; Tang, F.H.M. Analysis of the effect of organic matter content on the architecture and sinking of sediment aggregates. Mar. Geol. 2015, 363, 102-111. [CrossRef]

19. Van der Lee, W.T.B. Temporal variation of \#oc size and settling velocity in the Dollard estuary. Cont. Shelf Res. 2000, 20, 1495-1511.

20. Van der Lee, W.T.B. Parameters affecting mud floc size on a seasonal time scale: The impact of a phytoplankton bloom in the Dollard estuary, The Netherlands. In Coastal and Estuarine Fine Sediment Transport Processes; McAnally, W.H., Mehta, A.J., Eds.; Elsevier Science: Amsterdam, The Netherlands, 2001; pp. 403-421.

21. Gwon, Y.; Lee, D.; Kim, D.; Jung, S.; Jung, S. An Analysis of Discharge and Water Level Changes Due to Weir (In the Case of the Waegwan and Nakdong Station in South Korea). In Proceedings of the 11th International Conference on Hydroinformatics; CUNY Academic Works: New York, NY, USA, 2014.

22. Seo, D.; Kim, M.; Ahn, J.H. Prediction of Chlorophyll-a Changes due to Weir Constructions in the Nakdong River Using EFDC-WASP Modelling. Environ. Eng. Res. 2012, 17, 95-102. [CrossRef]

23. Tekile, A.; Kim, I.; Kim, J. Mini-review on river eutrophication and bottom improvement techniques, with special emphasis on the Nakdong River. J. Environ. Sci. 2015, 30, 113-121. [CrossRef] [PubMed]

24. APAH; AWWA; WEF. 10200 H Chlorophyll. In Standard Methods for the Examination of Water and Wastewater, 21th ed.; American Water Works Association: Washington, DC, USA, 2005.

25. APAH; AWWA; WEF. 10200-Plankton Azide Modification. In Standard Methods for the Examination of Water and Wastewater, 21th ed.; American Water Works Association: Washington, DC, USA, 2005.

26. Korea Ministry of Environment. Official Water Quality Test Methods (in Korean); Ministry of Environment: Seoul, Korea, 2016.

27. Water Resources Management Information System. Available online: www.wamis.go.kr (accessed on 8 May 2017).

28. Water Information System. Available online: water.nier.go.kr (accessed on 8 May 2017).

29. Lee, B.J.; Schlautman, M.A. Effects of Polymer Molecular Weight on Adsorption and Flocculation in Aqueous Kaolinite Suspensions Dosed with Nonionic Polyacrylamides. Water 2015, 7, 5896-5909. [CrossRef]

30. Gorczyca, B.; Ganczarczyk, J. Image analysis of alum coagulated mineral suspensions. Environ. Technol. 1996, 17, 1361-1369. [CrossRef]

31. Yamashita, Y.; Jaffe, R.; Maie, N.; Tanoue, E. Assessing the dynamics of dissolved organic matter (DOM) in coastal environments by excitation emission matrix fluorescence and parallel factor analysis (EEM-PARAFAC). Limnol. Oceanogr. 2008, 53, 1900-1908. [CrossRef]

32. Weishaar, J.; Aiken, G.R.; Bergamaschi, B.A.; Fram, M.S.; Fujii, R.; Mopper, K. Evaluation of Specific Ultraviolet Absorbance as an Indicator of the Chemical Composition and Reactivity of Dissolved Organic Carbon. Environ. Sci. Technol. 2003, 37, 4702-4708. [CrossRef] [PubMed]

33. Hur, J.; Cho, J. Prediction of BOD, COD, and total nitrogen concentrations in a typical urban river using a fluorescence excitation-emission matrix with PARAFAC and UV absorption indices. Sensors 2012, 12, 972-986. [CrossRef] [PubMed]

34. Yang, L.; Han, D.H.; Lee, B.M.; Hur, J. Characterizing treated wastewaters of different industries using clustered fluorescence EEM-PARAFAC and FT-IR spectroscopy: Implications for downstream impact and source identification. Chemosphere 2015, 127, 222-228. [CrossRef] [PubMed]

35. Stedmon, C.A.; Bro, R. Characterizing dissolved organic matter fluorescence with parallel factor analysis: A tutorial. Limnol. Oceanog. Methods 2008, 6, 572-579. [CrossRef]

36. Kalbitz, K.; Schmerwitz, J.; Schwesig, D.; Matzner, E. Biodegradation of soil-derived dissolved organic matter as related to its properties. Geoderma 2003, 113, 273-291. [CrossRef]

37. Zsolnay, A.; Baigar, E.; Jimenez, M.; Steinweg, B.; Saccomandi, F. Differentiating with fluoresence spectroscopy the sources of dissolved organic matter in soils subjected to drying. Chemosphere 1999, 38, 45-50. [CrossRef]

38. Wehr, J.D.; Descy, J.P. Use of phytoplankton in large river management. J. Phycol. 1998, 34, 741-749. [CrossRef] 
39. Coble, P.G. Characterization of marine and terrestrial DOM in seawater using excitation-Emission matrix spectroscopy. Mar. Chem. 1996, 51, 325-346. [CrossRef]

40. Coble, P.G.; Del Castillo, C.E.; Avril, B. Distribution and optical properties of CDOM in the Arabian Sea during the 1995 southwest monsoon. Deep Sea Res. Part II 1998, 45, 2195-2223. [CrossRef]

41. Osburn, C.L.; Handsel, L.T.; Mikan, M.P.; Paerl, H.W.; Montgomery, M.T. Fluorescence Tracking of Dissolved and Particulate Organic Matter Quality in a River-Dominated Estuary. Environ. Sci. Technol. 2012, 46, 8628-8636. [CrossRef] [PubMed]

42. Sheng, G.P.; Yu, H.Q. Characterization of extracellular polymeric substances of aerobic and anaerobic sludge using three-dimensional excitation and emission matrix fluorescence spectroscopy. Water Res. 2006, 40, 1233-1239. [CrossRef] [PubMed]

43. Zhang, Y.; Zhang, E.; Yin, Y.; van Dijk, M.A.; Feng, L.; Shi, Z.; Liu, M.; Qin, B. Characteristics and sources of chromophoric dissolved organic matter in lakes of the Yungui Plateau, China, differing in trophic state and altitude. Limnol. Oceanogr. 2010, 55, 2645-2659. [CrossRef]

44. Bade, D.L.; Carpenter, S.R.; Cole, J.J.; Pace, M.L.; Kritzberg, E.; Van de Bogert, M.C.; Cory, R.M.; McKnight, D.M. Sources and fates of dissolved organic carbon in lakes as determined by whole-lake carbon isotope additions. Biogeochemistry 2007, 84, 115-129. [CrossRef]

45. Rautio, M.; Mariash, H.; Forsstrom, L. Seasonal shifts between autochthonous and allochthonous carbon contributions to zooplankton diets in a subarctic lake. Limnol. Oceanogr. 2011, 56, 1513-1524. [CrossRef]

46. Fettweis, M.; Baeye, M.; Van der Zande, D.; Van den Eynde, D.; Lee, B.J. Seasonality of floc strength in the southern North Sea. J. Geophys. Res. Oceans 2014, 119, 1911-1926. [CrossRef]

47. Grossart, H.; Simon, M.; Logan, B.E. Formation of macroscopic organic aggregates (lake snow) in a large lake: The significance of transparent exopolymer particles, plankton, and zooplankton. Limnol. Oceanogr. 1997, 42, 1651-1659. [CrossRef]

48. Passow, U. Transparent exopolymer particles (TEP) in aquatic environments. Prog. Oceanogr. 2002, 55, 287-333. [CrossRef]

49. Beckett, R. Surface and Colloid Chemistry in Natural Waters and Water Treatment; Springer Science + Business: New York, NY, USA, 1990.

50. Jekel, M.R. The stabilization of dispersed mineral particles by adsorption of humic substances. Water Res. 1986, 20, 1543-1554. [CrossRef]

51. Thurman, E.M. Organic Geochemistry of Natural Waters; Martinus Nijhoff/Dr W. Junk Publishers: Dordrecht, The Netherlands, 1985.

52. Bainbridge, Z.; Wolnaski, E.; Alvarez-Romero, J.G.; Lewis, S.E.; Brodie, J.E. Fine sediment and nutrient dynamics related to particle size and floc formation in a Burdekin River flood plume, Australia. Mar. Pollut. Bull. 2012, 65, 236-248. [CrossRef] [PubMed]

53. Tang, F.H.M.; Maggi, F. A mesocosm experiment of suspended particulate matter dynamics in nutrient-and biomass-affected waters. Water Res. 2016, 89, 76-86. [CrossRef] [PubMed]

54. Fleer, G.; Cohen Stuart, M.; Scheutjens, J.; Cosgrove, T. Polymers at Interfaces; Chapman \& Hall: London, UK, 1993.

55. Philippe, A.; Schaumann, G.E. Interactions of Dissolved Organic Matter with Natural and Engineered Inorganic Colloids: A Review. Environ. Sci. Technol. 2014, 48, 8946-8962. [CrossRef] [PubMed]

56. Xu, H.; Yang, C.; Jiang, H. Aggregation kinetics of inorganic colloids in eutrophic shallow lakes: Influence of cyanobacterial extracellular polymeric substances and electrolyte cations. Water Res. 2016, 106, 344-351. [CrossRef] [PubMed]

57. Elfarissi, F.; Nabzar, L.; Ringenbach, E.; Pefferkorn, E. Polyelectrolytic nature of humic substances-aluminum ion complexes Interfacial characteristics and effects on colloid stability. Colloids Surfaces A Physicochem. Eng. Asp. 1998, 131, 281-294. [CrossRef]

58. Kretzschmar, R.; Holthoff, H.; Sticher, H. Influence of $\mathrm{pH}$ and Humic Acid on Coagulation Kinetics of Kaolinite: A Dynamic Light Scattering Study. J. Colloid Interface Sci. 1998, 202, 95-103. [CrossRef]

(C) 2017 by the authors. Licensee MDPI, Basel, Switzerland. This article is an open access article distributed under the terms and conditions of the Creative Commons Attribution (CC BY) license (http:/ / creativecommons.org/licenses/by/4.0/). 